\title{
Evaluation of quality and variety of Indonesian cassava (Manihot esculenta Crantz)
}

\author{
Amarullah \\ Received 28 April 2020, Revised 19 May 2020, Accepted 20 June 2020, Published online 30 June 2020
}

\section{A B S T R A C T}

The evaluating cassava varieties for productivity necessary to assess the cassava stem characteristics for their suitability as planting material and to improve the capability of cassava farmers to select good quality cassava varieties. Cassava varieties are generally distinguished from each other by their morphological characteristics, which include leaf, stem and tuber colour. The cassava planting material used in this study and some of characteristics by five cassava varieties, consisted of mature stem cuttings of about $20 \mathrm{~cm}$ in length, containing between 10 and 12 nodes and planted in a vertical position along the top of the ridges. Each plot consisted of 30 plants, with date being taken from ten plants within each plot. Cassava varieties Malang-6 presented the highest yield average is 13.81 tones ha-1 followed by Singgah and Adira-4 i.e. $11.98 \mathrm{t} \mathrm{ha}^{-1}$ and $11.11 \mathrm{t} \mathrm{ha}^{-1}$ of different varieties 1 yang Ketan, which only weighs $6.63 \mathrm{t} \mathrm{ha}^{-1}$. Harvest index varieties of Adira-4, Malang-6, UJ 5 and Singgah were found $0.78,0.77,0.77$ and 0.76 , respectively higher and significantly different IP varieties of glutinous Ketan is 0.58. Malang varieties and Malang-6 that produces the highest tuber weight, has a low dry matter content is $5.65 \%$ and $5.62 \%$. The Ketan varieties and UJ-5 has a tuber weight was significantly lower with dry matter content higher than that dried $8.69 \%$ and $8.68 \%$. The UJ-5 varieties has a tuber weight starch HCN 230,17 higher and significantly other variety.

Keywords: Evaluation, Quality, Cassava variety.

Department of Agronomy, Faculty of Agriculture, University of Borneo Tarakan, Jl. Amal Lama 1, Tarakan. North Borneo, Indonesia.

*Corresponding author's email: amarullah70@gmail.com (Amarullah)

Cite this article as: Amarullah. 2020. Evaluation of quality and variety of Indonesian cassava (Manihot esculenta Crantz). Int. J. Agril. Res. Innov. Tech. 10(1): 108-116. https://doi.org/10.3329/ijarit.v10i1.48102

\section{Introduction}

Cassava (Manihot esculenta Crantz) is one of the most important crops in the tropics (Nnodu et al., 2006; Ikeh et al., 2012) and subtropics around the world (Raji et al., 2009; Perera et al., 2013), globally, cassava plant is the sixth most important after wheat, rice, potatoes, corn and barley, and became a staple food for more than 800 million people in the world, especially in tropical countries (Lebot, 2009; Ladeira et al., 2013) while in Indonesia, cassava is the third staple food after rice and maize (Ristono and Amarullah, 2011).

Prospects for the development of cassava commodities continued to increase in line with the increasing diversification of needs for raw materials are sourced from cassava. In some countries, cassava is the staple food and some are used for processed into food alternatives. The economic value of cassava can be enhanced when used as biofuels, especially with the depletion of world oil reserves that make cassava demand is increasing in some other countries (Amarullah et al., 2016).

According to Alexandratos (1995), cassava plays an important role in alleviating food problems, because it thrives and produces stable yields under conditions in which other crops fail. Cassava is a versatile crop and can be processed into a wide range of products such as starch, flour, tapioca, beverages and cassava chips for animal feed. Cassava is also gaining prominence as an important crop for the emerging biofuel industry and, as corroborated by Ziska et al. (2009), is a potential carbohydrate source for ethanol production. A well planned strategy for the development and utilization of cassava and cassava products can provide incentives for farmers, crop vendors and food processors to increase their incomes. It can also provide food security for households producing, consuming cassava products (Plucknett et al., 1998). 
Traditionally, cassava has been grown by farmers throughout the Indonesian and has been of particular importance to small farmers, where it is still cultivated. It is a crop that is generally grown on marginal lands with a minimum of agricultural 2 inputs (Hillocks et al., 2002). Once established, the cassava crop is given little attention, but still is able to tolerate weed competition, as well as insect pests and diseases. The potential exists for improving the productivity of cassava through better agronomic practices, superior varieties and pest and disease management.

Cassava varieties are generally distinguished from each other by their morphological characteristics, which include leaf, stem and tuber colour, leaf shape and number of storage roots per plant. The plant produces all year round and can be harvested over an extended period. Although it is easily propagated by stem cuttings, the lack of quality planting material is a major constraint to the development of a viable cassava production system. Eze and Ugwuoke (2010) report that tuber yield of cassava is influenced by both the quality of planting material used and the agronomic practices employed. Access to high yielding cassava varieties and an improvement of the production system will result in increased economic benefits to local farmers.

Among the objectives of the seed and tuber crops programme by Balitkabi at the Malang Indonesian are to identify high yielding cassava varieties, to evaluate and preserve cassava germplasm and to provide good quality planting material for local farmers. Documented information on the performance of cassava on the inceptisol soils of Java, under improved agronomic practices, is lacking. Until this present study, very little effort had been made to evaluate existing varieties and new introductions for their yield potential under local conditions. Consequently, there is a need for conducting research on cassava in order to identify varieties suitable for growing on Java soils. The productivity of this crop can be improved through the selection of cassava varieties are most suitable for local conditions and the application of the appropriate agronomic practices

\section{Objectives}

The objectives of this study were to evaluate five cassava varieties for their productivity on Java soils, to assess the cassava stem characteristics for their suitability as planting material and to improve the capability of local farmers to select good quality cassava varieties.

\section{Materials and Methods}

\section{Experiment site}

The study was carried out at the experiment, Gajah Mada University, Yogyakarta, from February 2013 to September 2013. Research station is situated at altitude $113 \mathrm{~m}$ above mean sea level.

\section{Experiment design}

The cassava planting materials used in this study and some of characteristics by variety are listed in Table 1. These varieties are already a part of the production systems of local farmers. Though no nutritional studies have been done to determine the levels of hydrogen cyanide $(\mathrm{HCN})$ within their edible portions, they have been designated by farmers as sweet cassava varieties, with apparently low HCN contents. To date, there have been no reports of HCN toxicity with any of the three varieties evaluated. Their origins could not be independently verified at the time of this study; the information found in Table 1 was obtained from the farmers who supplied the plant material, or identified it as such from stock plants growing at the Balitkabi, Malang Indonesia.

Table 1. Cassava varieties used as planting material for cassava tests.

\begin{tabular}{|c|c|c|c|c|}
\hline No & Variety & Origin & Status variety & Description \\
\hline 1 & Adira-4 & $\begin{array}{l}\text { Balitkabi, Malang } \\
\text { Indonesian }\end{array}$ & VUB National & Early branching, erect \\
\hline 2 & Malang-6 & $\begin{array}{l}\text { Balitkabi, Malang } \\
\text { Indonesian }\end{array}$ & VUB National & $\begin{array}{l}\text { Early branching, } \\
\text { spreading }\end{array}$ \\
\hline 3 & UJ-5 & $\begin{array}{l}\text { Balitkabi, Malang } \\
\text { Indonesian }\end{array}$ & VUB National & $\begin{array}{l}\text { Early branching, } \\
\text { spreading, menyebar }\end{array}$ \\
\hline 4 & Singgah & $\begin{array}{l}\text { Park P3SG UBT } \\
\text { Tarakan } \\
\text { North Borneo }\end{array}$ & $\begin{array}{l}\text { Local Variety North Borneo } \\
\text { (Promotion) }\end{array}$ & Late branching, erect \\
\hline 5 & Ketan & $\begin{array}{l}\text { Balitkabi, Malang } \\
\text { Indonesian }\end{array}$ & $\begin{array}{l}\text { Local Variety Ponorogo East } \\
\text { Java, Indonesian } \\
\text { (Balance sample) }\end{array}$ & $\begin{array}{l}\text { Early branching, } \\
\text { spreading }\end{array}$ \\
\hline
\end{tabular}

Balitkabi: Research Institute for Nuts and Tubers; P3SG UBT: Research and Development Center for Elephant Cassava, University of Borneo Tarakan; VUB: new high yielding varieties; Stop: Cassava Elephant; East Java: East Java. 
The five cassava varieties evaluated in this experiment were established in an open field in a block randomized design with four replications, on ridges $1.5 \mathrm{~m}$ apart, with a $1.0 \mathrm{~m}$ spacing between plants within rows. The planting material consisted of mature stem cuttings of about $20 \mathrm{~cm}$ in length, containing between 10 and 12 nodes and planted in a vertical position along the top of the ridges. Each plot consisted of 30 plants, with data being taken from ten plants within each plot. Tuber yield was determined from the actual area of each plot, which, according to Romani et al. (1993), provides a good estimate of true yield. This is also supported by Neppl et al. (2003) whose study indicated that interactions of centre row with border row were insignificant.

The usual cultural practices were observed to ensure an even stand of plants in the experimental plots. The cassava trial plots were grown under rain-fed conditions. Fertilizer was applied at a rate of $250 \mathrm{~kg}$ per hectare $(223 \mathrm{lb}$ per acre) one month after planting, then again at three months after planting. Before each application of fertilizer, the plots were weeded and cultivated. Plant characteristics (Table 2) were described according to the descriptor list for cassava genetic resources (CIAT, 2009).

Table 2. Observed cassava plant characteristics and rating system (CIAT, 2009)

\begin{tabular}{|c|c|c|c|}
\hline No & Characteristics & $\begin{array}{l}\text { Determination } \\
\text { Method }\end{array}$ & Key \\
\hline 1 & $\begin{array}{l}\text { Colour of first fully } \\
\text { expanded leaf }\end{array}$ & $\begin{array}{l}\text { Observing and } \\
\text { estimating }\end{array}$ & $\begin{array}{l}\text { 1. Light green, 2. Dark green, 3. Green-purple), } \\
\text { 4. Purple }\end{array}$ \\
\hline 2 & $\begin{array}{l}\text { Shape of central leaf } \\
\text { lobe }\end{array}$ & $\begin{array}{l}\text { Observing and } \\
\text { estimating }\end{array}$ & $\begin{array}{l}\text { 1. Oblanceolate, 2. Linear, 3. Elliptic, } 4 . \\
\text { Pandurate , 5. Lanceolate, 6. Other }\end{array}$ \\
\hline 3 & $\begin{array}{l}\text { Colour of } \\
\text { unexpanded apical } \\
\text { leaves }\end{array}$ & $\begin{array}{l}\text { Observing and } \\
\text { estimating }\end{array}$ & $\begin{array}{l}\text { 1. Light green, 2. Dark green, 3. Green-purple, } \\
\text { 4. Purple, 5. Other }\end{array}$ \\
\hline 4 & $\begin{array}{l}\text { Pubescence of } \\
\text { young } \\
\text { Leaves }\end{array}$ & $\begin{array}{l}\text { Observing and } \\
\text { estimating }\end{array}$ & 1. Sparse, 2. Intermediate, 3. Dense \\
\hline 5 & Petiole colour & $\begin{array}{l}\text { Observing and } \\
\text { estimating }\end{array}$ & $\begin{array}{l}\text { 1. Light green, 2. Dark green, 3. Green-purple, } \\
\text { 4. Purple, 5. Other }\end{array}$ \\
\hline 6 & Stem colour & $\begin{array}{l}\text { Observing and } \\
\text { estimating }\end{array}$ & $\begin{array}{l}\text { 1. Silver green, 2. Light brown or orange, } 3 \text {. } \\
\text { Dark brown, } 4 \text {. Other }\end{array}$ \\
\hline 7 & $\begin{array}{l}\text { Storage roots per } \\
\text { plant }\end{array}$ & Counting & \\
\hline 8 & $\begin{array}{l}\text { Storage root pulp } \\
\text { colour }\end{array}$ & $\begin{array}{l}\text { Observing and } \\
\text { estimating }\end{array}$ & 1. White or cream, 2. Yellow, 3. Pink, 4. Other \\
\hline 9 & $\begin{array}{l}\text { Storage root surface } \\
\text { colour }\end{array}$ & $\begin{array}{l}\text { Observing and } \\
\text { estimating }\end{array}$ & $\begin{array}{l}\text { 1. White, 2. Cream, 3. Light brown, 4. Dark } \\
\text { brown, 5. Other }\end{array}$ \\
\hline 10 & $\begin{array}{l}\text { Colour of outer } \\
\text { surface of storage } \\
\text { root cortex }\end{array}$ & $\begin{array}{l}\text { Observing and } \\
\text { estimating }\end{array}$ & 1.White, 2. Yellow, 3.Pink, 4. Purple, 5. Other \\
\hline
\end{tabular}

Farming practices commonly observed to ensure even stand of plants in the experimental plots. Cassava planted in experimental plots during the dry season. Urea fertilizer, $\mathrm{SP}_{3} 6$ and $\mathrm{KCl}$ was applied at a rate of 200,100 , and $100 \mathrm{~kg} \mathrm{ha}^{-1}$, given half a dose at age 1 month after planting (bst), then the rest is given again at age 3 bst. Before the application of fertilizers, which weeded plots of weeds, while manure is given at age 1 bst with a dose of $20 \mathrm{t} \mathrm{ha}^{-1}$. Plant characteristics are presented in Table 2, according to a list of descriptions of cassava genetic resources (CIAT, 2009).

The minimum and maximum monthly temperature average for the trial period each $20^{\circ} \mathrm{C}$ and $28^{\circ} \mathrm{C}$, total rainfall of $1,124 \mathrm{~mm}$ and the duration of sunlight monthly average for the period was 7.7 hours. Ten months after planting, in a plot harvested cassava and tubers counted, weighed and measured. Data taken from ten plants randomly selected from each experimental plot. The parameters observed and measured include; the number of tubers per plant (grain), root length $(\mathrm{cm})$, root diameter $(\mathrm{cm})$, weight of each tuber $(\mathrm{g})$, total tuber yield per plant $(\mathrm{kg})$, and the harvest index (IP). In addition, the following trunk characteristics were evaluated: plant height $(\mathrm{cm})$, number of segments, stem diameter $(\mathrm{cm})$, segment length $(\mathrm{cm})$ and number of primary branches. Plant height is measured from the base of the plant to the highest tops.

Samples of the tubers harvested for each of the five varieties of cassava to be analyzed HCN and starch content of the Food Science Laboratory FTP UGM. Varieties of cassava tuber samples are weighed in water, 1.5 or $3.0 \mathrm{~kg}$ to determine the 
value of dry matter. Analysis of N, P and $\mathrm{K}$ of total land is analyzed in the laboratory of soil science FP UGM to determine the level of absorption and utilization of nutrients $\mathrm{N}, \mathrm{P}$ and $\mathrm{K}$ by each variety of cassava.

\section{Statistical analysis}

Data were analyzed by analysis of variance (ANOVA). The values with significant differences were tested further with; Duncan's multiple range test (DMRT) at $5 \%$ level of significance. The data is processed and analyzed using Excel Program continued into portable 9.1.3 SAS program (SAS, 2004).

\section{Results and Discussion}

Five cassava varieties were evaluated for their morphological characteristics according to morphological characteristics of cassava plants (Table 3). No signs of harmful pests or diseases on the leaves, stems and roots during this trial period were observed. During the growing season, there are many leaves are falling, and there is probably not too have adverse effects on tuber yields. Decreased level of production, leaf and root dry weight can occur at temperatures too low even reaching $17^{\circ} \mathrm{C}$ (Alves, 2002), but (Irikura et al. (1979) have found that the same cassava varieties can produce higher production at various temperatures, this shows that the effect of natural selection is very significant on the adaptation of varieties. These varieties are distinguished from one another based on their leaves, stems and tubers characteristics. Variations encountered in the characteristics of the five varieties of cassava in this study. Cassava Adira-4, Malang-6 and UJ-5 has a dark tuber surface with white flesh and a light yellow cortex, while the Transit and sticky rice varieties tend to be the same as the tuber flesh is white with white storage root surface and cortex crimson

Table 3. Morphological characteristics of cassava plant.

\begin{tabular}{|c|c|c|c|c|c|c|}
\hline \multirow[t]{2}{*}{ Parameter } & \multicolumn{5}{|c|}{ Characteristics } & \multirow[t]{2}{*}{ Information } \\
\hline & Adira-4 & Malang-6 & UJ-5 & Singgah & Ketan & \\
\hline \multicolumn{7}{|l|}{ Observing age 3 MAP } \\
\hline 1. Color of Leaf Buds & 1 & 1 & 2 & 1 & 1 & $\begin{array}{l}\text { 1. Light green } \\
\text { 2. Dark green (Hijau Gelap) } \\
\text { 3. Purplish green } \\
\text { 4. Purple } \\
\end{array}$ \\
\hline 2. Pubertas of leaf buds & $\mathrm{O}$ & $\mathrm{O}$ & $\mathrm{O}$ & $\mathrm{O}$ & $\mathrm{O}$ & $\begin{array}{l}\text { O. Absent } \\
\text { 1. Present }\end{array}$ \\
\hline \multicolumn{7}{|l|}{ Observing age 6 MAP } \\
\hline 3. Leaf retention & 2 & 1 & 3 & 2 & 3 & $\begin{array}{l}\text { 1. Very poor retention } \\
\text { 2. Less than average retention } \\
\text { 3. Average retention } \\
\text { 4. Better than average retention } \\
\text { 5. Outstanding leaf retention }\end{array}$ \\
\hline 4. Central leaflet & 1 & 2 & 2 & 2 & 1 & $\begin{array}{l}\text { 1. Ovoid } \\
\text { 2. Elliptic-lanceolate }\end{array}$ \\
\hline 5. Petiole color & 1 & 4 & 3 & 6 & 6 & $\begin{array}{l}\text { o. Yellowish-green, 3. Green } \\
\text { 4. Reddish-green, 5. Greenish- } \\
\text { red, 6. Red, 7. Purple }\end{array}$ \\
\hline 6. Leaf color & 2 & 1 & 2 & 1 & 2 & $\begin{array}{l}\text { 1. Light green, Dark green } \\
\text { 2. Purple green, Purple }\end{array}$ \\
\hline 7. Number of leaf lobes & 6.7 .8 & $4,5,6.7 .8$ & $4,5,6$ & $3,4,5,6,7$ & $4,5,6.7$ & $\begin{array}{l}\text { 1. } 3 \text { leaf; } 2.4 \text { leaf; } 3.5 \text { leaf; } 4.6 \\
\text { leaf; } 5.7 \text { leaf; } 6.8 \text { leaf; } 7.9 \text { leaf. } \\
8.10 \text { leaf; } 9.11 \text { leaf }\end{array}$ \\
\hline 8. Length of leaf lobe & $12-27$ & $17-36$ & $19-34$ & $19-34$ & $12-29$ & leaf located in the middle \\
\hline 9. Width of leaf lobe & $1.2-4.7$ & $2.4-8.6$ & $2.0-7.9$ & $2.1-7.8$ & $1.2-6.9$ & leaf located in the middle \\
\hline $\begin{array}{l}\text { 10. Ratio of lobe length to } \\
\text { lobe width of central leaf } \\
\text { lobe }\end{array}$ & $5 / 1$ & $4 / 1$ & $4 / 1$ & $4 / 1$ & $3 / 1$ & - \\
\hline 11. Lobe margins & 1 & 2 & 1 & 2 & 1 & 1. Smooth, 2. Winding \\
\hline 12. Petiole length & $18-30$ & $30-35$ & $20-32$ & $29-39$ & $23-31$ & $\mathrm{~cm}$ \\
\hline 13. Color of leaf vein & 1 & 1 & 1 & 1 & 1 & $\begin{array}{l}\text { 1. Green, 2. Reddish-green in } \\
\text { less than half of the lobe } \\
\text { 3. Reddish-green in more than } \\
\text { half of the lobe, } 4 \text {. All red }\end{array}$ \\
\hline 14. Orientation of petiole & 1 & 3 & 4 & 2 & 2 & $\begin{array}{l}\text { 1. Inclined upwards, } 2 . \\
\text { Horizontal, } 3 \text {. Inclined } \\
\text { downwards, 4. Irregular }\end{array}$ \\
\hline 15. Flowering & 2 & 2 & 2 & 2 & 2 & 1. Absent, 2. Present \\
\hline 16. Pollen & 2 & 2 & 2 & 2 & 2 & 1. Absent, 2.Present \\
\hline \multicolumn{7}{|l|}{ Observing age 9 MAP } \\
\hline $\begin{array}{l}\text { 17. Prominent of foliar } \\
\text { scarsce }\end{array}$ & 2 & 2 & 1 & 2 & 2 & $\begin{array}{l}\text { 1. Semi-prominent } \\
\text { 1. Prominent }\end{array}$ \\
\hline 18. Color of stem cortex & 2 & 2 & 2 & 2 & 2 & $\begin{array}{l}\text { 1. Orange, 2. Light green, } 3 \text {. } \\
\text { Dark green }\end{array}$ \\
\hline
\end{tabular}




\begin{tabular}{|c|c|c|c|c|c|c|}
\hline $\begin{array}{l}\text { 19. Color of stem } \\
\text { epidermis }\end{array}$ & 2 & 2 & 2 & 2 & 2 & $\begin{array}{l}\text { 1. Cream, 2. Light brown } \\
\text { 3. Dark brown, Orange }\end{array}$ \\
\hline 20. Color of stem exteriors & 2 & 7 & 2 & 3 & 3 & $\begin{array}{l}\text { 1. Orange, 2. Greenish- } \\
\text { yellowish, 3. Golden }\end{array}$ \\
\hline $\begin{array}{l}\text { 21. Distance between leaf } \\
\text { scars }\end{array}$ & 3 & 3 & 3 & 3 & 3 & $\begin{array}{l}\text { 1. Short }(<8 \mathrm{~cm}), 2 . \text { Medium } \\
(8-15 \mathrm{~cm}) \text {, 3.Long }(>15 \mathrm{~cm})\end{array}$ \\
\hline 22. Growth habit of stem & 1 & 1 & 1 & 1 & 1 & 1. Straight, 2. Zig-zag \\
\hline 23. Color of end branches & 1 & 1 & 2 & 2 & 2 & $\begin{array}{l}\text { 1. Green, 2. Green-purple, } 3 . \\
\text { Purple }\end{array}$ \\
\hline 24. Length of stipules & 1 & 1 & 1 & 1 & 1 & 1. Short, 2. Long \\
\hline 25. Stipule margin & 1 & 1 & 1 & 1 & 1 & 1. Entire, 2. Split or forked \\
\hline \multicolumn{7}{|l|}{ Observing Harvest } \\
\hline 26. Plant height & $2.7-3.1$ & $2.3-2.9$ & $2.5-3.0$ & $2.8-3.4$ & $25 \cdot 3.2$ & $\mathrm{~cm}$ \\
\hline $\begin{array}{l}\text { 27. Height to first } \\
\text { branching }\end{array}$ & $\begin{array}{c}1 \\
(180-245) \\
\end{array}$ & $\begin{array}{c}2 \\
(50-220) \\
\end{array}$ & $\begin{array}{c}2 \\
(10-180) \\
\end{array}$ & $\begin{array}{c}1 \\
(70-240) \\
\end{array}$ & $\begin{array}{c}1 \\
(40-120) \\
\end{array}$ & $\begin{array}{l}\text { 1. Primary Branch }(\mathrm{cm}) \\
\text { 2. Second Branch }(\mathrm{cm})\end{array}$ \\
\hline 28. Level of branching & 3 & 2 & 3 & 3 & 5 & \\
\hline 29. Branching habit & $2 / 3$ & $1 / 5$ & $2 / 3$ & $2 / 3$ & $2 / 3 / 4$ & $\begin{array}{l}\text { 1. Erect, 2. Dichotomous } \\
\text { 1. Trichotomous } \\
\text { 2. Tetrachotomous, 5.Irreguler }\end{array}$ \\
\hline 30. Angle of branching & $70-145$ & $60-80$ & $50-90$ & $45-90$ & $70-120$ & $\mathrm{O}$ \\
\hline 31. Shape of plant & 3 & 4 & 2 & 3 & 3 & $\begin{array}{l}\text { 1. Compact, 2. Open } \\
\text { 3. Umbrella, 4. Cylindrical }\end{array}$ \\
\hline $\begin{array}{l}\text { 32. Number of storage } \\
\text { roots/plant }\end{array}$ & $4-11$ & $4-11$ & 5-13 & $5-14$ & $5-12$ & all tubers are formed \\
\hline $\begin{array}{l}\text { 33. Number of } \\
\text { commercial roots/plant }\end{array}$ & $4-10$ & $4-11$ & $5-9$ & $5-14$ & $5-12$ & $\begin{array}{l}3 \text { tubers with a length of more } \\
\text { than } 20 \mathrm{~cm}\end{array}$ \\
\hline $\begin{array}{l}\text { 34. Extent of root } \\
\text { peduncle }\end{array}$ & 1 & 1 & 1 & 1 & 1 & $\begin{array}{l}\text { 1. Sessile, 2. Pedunculate } \\
\text { 1. Mixed }\end{array}$ \\
\hline 35. Root constrictions & 1 & 1 & 3 & $1 / 2$ & $1 / 2$ & $\begin{array}{l}\text { 1. Few to none, 2. Some, } 3 \text {. } \\
\text { Many }\end{array}$ \\
\hline 36. Root shape & $1 / 2 / 3$ & $3 / 4$ & $1 / 3$ & $2 / 4$ & 4 & $\begin{array}{l}\text { 1. Conical, 2. Conical- } \\
\text { cylindrical } \\
\text { 2. Cylindrical, 4. Irregular }\end{array}$ \\
\hline $\begin{array}{l}\text { 37. External color of } \\
\text { storage root }\end{array}$ & 3 & 1 & 2 & $3 / 4$ & $3 / 4$ & $\begin{array}{l}\text { 1. White or cream, 2. Yellow } \\
\text { 3. Light brown, } 4 \text {. Dark brown }\end{array}$ \\
\hline 38. Color of root pulp & 2 & 2 & 2 & 1 & 1 & 1. White, 2. Cream \\
\hline 39. Color of root cortex & 1 & 2 & 2 & 4 & 4 & $\begin{array}{l}\text { 1. White or cream, 2. Yellow, } 3 . \\
\text { Pink, 4. Purple }\end{array}$ \\
\hline 40. Cortex & 2 & 2 & 2 & 2 & 2 & 1. Easy, 2. Difficult \\
\hline $\begin{array}{l}\text { 41. Texture of root } \\
\text { epidermis }\end{array}$ & 3 & 1 & 1 & 3 & 3 & $\begin{array}{l}\text { 1. Smooth, 2. Intermediate, } \\
\text { 3. Rough }\end{array}$ \\
\hline 42. Root taste & 3 & 1 & 1 & 3 & 3 & $\begin{array}{l}\text { 1. Sweet, 2. Intermediate, } \\
\text { 3. Bitter }\end{array}$ \\
\hline 43. Cortex thickness & 3 & 1 & 1 & 3 & 3 & $\begin{array}{l}\text { 1. Thin, 2. Intermediate, } 3 \text {. } \\
\text { Thick }\end{array}$ \\
\hline 44. Dry matter content & 1.20 & 0.91 & 1.05 & 1.02 & 0.85 & 3 plant \\
\hline 45. Starch content & 23.06 & 27.29 & 29.57 & 25.64 & 28.26 & 3 plant \\
\hline 46. Harvest index & 0.49 & 0.42 & 0.46 & 0.48 & 0.39 & 4-6 plant/varieties \\
\hline $\begin{array}{l}\text { 47. Cyanogen } \\
\text { potential/CNP }\end{array}$ & 108.19 & 109.33 & 236.84 & 133.64 & 100.44 & (mg/10og) \\
\hline
\end{tabular}

Analysis of the performance characteristics of height, number of segments, stem diameter and stem growth are presented in Table 4, showed a number of primary branches are significant at $1 \%$ significant response to the parameters of the level of confidence, while the segment length is results of the five varieties of cassava. Plant significant at $5 \%$ level.

Table 4. Plant height conditions, number of segments and branch conditions on five cassava varieties in one plant per $\mathrm{m}^{2}$ age $9 \mathrm{MAP}$.

\begin{tabular}{|c|c|c|c|c|c|c|}
\hline Varieties & $\begin{array}{l}\text { Plant height } \\
(\mathrm{cm})\end{array}$ & $\begin{array}{c}\text { Number } \\
\text { of } \\
\text { segments }\end{array}$ & $\begin{array}{c}\text { Stem } \\
\text { Diameter } \\
(\mathrm{cm})\end{array}$ & $\begin{array}{l}\text { Number } \\
\text { of } \\
\text { branch }\end{array}$ & $\begin{array}{l}\text { Branch } \\
\text { level }\end{array}$ & shape and angle of the branch \\
\hline Adira $4\left(V_{1}\right)$ & 293.04ab & $142.44 \mathrm{~b}$ & $3.20 \mathrm{~b}$ & $2.60 \mathrm{~b}$ & $1.98 \mathrm{~b}$ & Umbrella, $\left(35^{-60^{0}}\right)$ \\
\hline $\begin{array}{l}\text { Malang } 6 \\
\left(\mathrm{~V}_{2}\right)\end{array}$ & $274.23 \mathrm{~b}$ & $163.90 a$ & 3.56 & $4 \cdot 33 \mathrm{a}$ & $1.20 d$ & $\begin{array}{l}\text { Cylindrical, lateral branches } \\
\text { and Irregular, }\left(35-50^{\circ}\right)\end{array}$ \\
\hline UJ $5\left(V_{3}\right)$ & $241.26 c$ & $110.43 \mathrm{~b}$ & $2.72 \mathrm{~d}$ & $1.76 \mathrm{~d}$ & $1.55 \mathrm{c}$ & 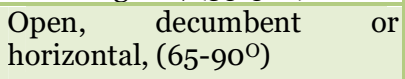 \\
\hline Singgah $\left(V_{4}\right)$ & $307.80 a$ & $120.82 b$ & $2.66 \mathrm{~cd}$ & $2.33 \mathrm{c}$ & $1.40 \mathrm{Oc}$ & Cylindrical, $\left(25^{-}-35^{\mathrm{O}}\right)$ \\
\hline $\operatorname{Ketan}\left(V_{5}\right)$ & $295 \cdot 33 a b$ & $138.27 \mathrm{~b}$ & $3.02 b c$ & $2.13 \mathrm{c}$ & $3.27 \mathrm{a}$ & Compact, $\left(50-70^{0}\right)$ \\
\hline
\end{tabular}

Note: Numbers in columns followed by the same letter show no difference according to the Duncan's test at $5 \%$ level. 
Analysis of variance test performed showed a significant difference between the responses for all five varieties of tuber yield. Data analysis (Table 4) shows the significance of the results of the tuber. Tuber yield is determined by the number, length, diameter and weight as well as weight of the tuber and tuber per plant. Bulbs separated into valuable and worthless bulbs, depending on the size and weight.

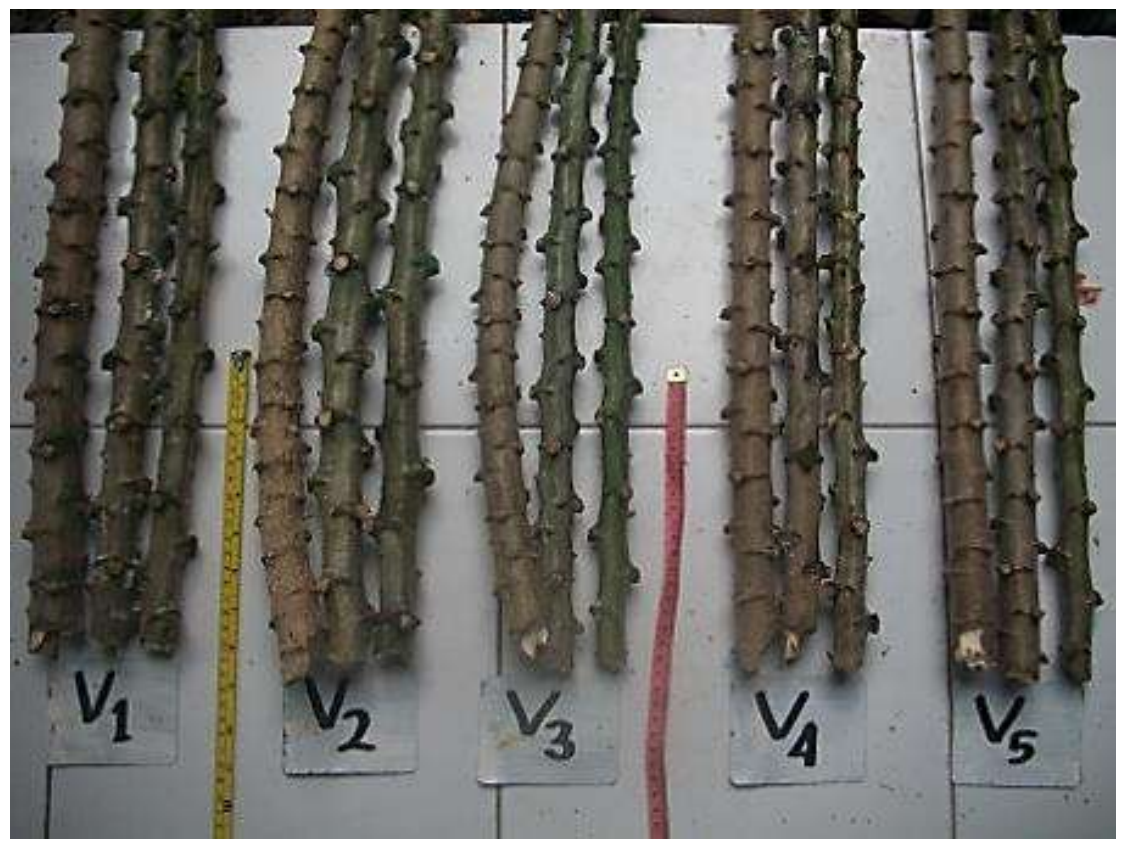

Fig. 1. Results of the stems of five cassava varieties aged 4 MAP; V: Cassava varieties; V1 Adira-4; V2: Malang-6; V3: UJ-5; V4: Singgah; V5: Ketan.

Based on the cassava harvest at the age of 9 bst obtained significant differences between the varieties of cassava to the parameters of tuber yield and harvest index. Weight of five cassava tuber crops increase until at harvest age 9 bst. The harvest index (IP) for five cassava varieties has increased since the age of 3-9 years but shows different results among the varieties, where the varieties of Adira-4, Malang-6, UJ-5 and Singgah IP show higher than Ketan varieties (Table 4).

Number and length of tuber of Singgah cassava variety was found more, longer and significantly different from the four other varieties. Cassava varieties Adira-4 and Malang-6 produces very

varieties produce small tubers that are uniform in size. This condition may make the plant more efficient in collecting the storage of carbohydrates in the roots. Higher number of tubers in the varieties Transit UJ-5 and Ketan not in line with the results of cassava tuber weight. These results supported the research results of Hayford (2009), which indicates that there is a negative correlation between the number of tubers per plant and mean weight of cassava tubers. Weight of tubers per plant was lower in glutinous varieties allegedly because of competition between the roots of the bulbs during the charging process. large diameter tubers, while the glutinous

Table 4. Tuber yields and harvest index (HI) of five cassava varieties.

\begin{tabular}{|l|rrrrrr|}
\hline Varieties & $\begin{array}{c}\text { Number of } \\
\text { Tuber }\end{array}$ & $\begin{array}{c}\text { Length of } \\
\text { tuber }(\mathrm{cm})\end{array}$ & $\begin{array}{c}\text { Diameter } \\
\text { of tuber } \\
(\mathrm{cm})\end{array}$ & $\begin{array}{r}\text { Weight of } \\
\text { tuber }(\mathrm{g})\end{array}$ & $\begin{array}{c}\text { Tuber weight } \\
\text { per plant }(\mathrm{kg})\end{array}$ & $\begin{array}{c}\text { Index } \\
\text { harvest } \\
(\mathrm{IP})\end{array}$ \\
\hline Adira-4 $\left(\mathrm{V}_{1}\right)$ & $9.11 \mathrm{~d}$ & $40.77 \mathrm{c}$ & $9.59 \mathrm{a}$ & $992.98 \mathrm{~b}$ & $11.11 \mathrm{c}$ & $0.78 \mathrm{a}$ \\
\hline Malang-6 $\left(\mathrm{V}_{2}\right)$ & $9.33 \mathrm{~d}$ & $64.40 \mathrm{~b}$ & $8.74 \mathrm{~b}$ & $1033.95 \mathrm{a}$ & $13.81 \mathrm{a}$ & $0.77 \mathrm{a}$ \\
\hline UJ-5 $\left(\mathrm{V}_{3}\right)$ & $10.67 \mathrm{~b}$ & $34.87 \mathrm{~d}$ & $7.12 \mathrm{~d}$ & $777.33 \mathrm{C}$ & $9.63 \mathrm{~d}$ & $0.77 \mathrm{a}$ \\
\hline Singgah $\left(\mathrm{V}_{4}\right)$ & $11.22 \mathrm{a}$ & $75.98 \mathrm{a}$ & $7.75 \mathrm{c}$ & $1053.02 \mathrm{a}$ & $11.98 \mathrm{~b}$ & $0.76 \mathrm{a}$ \\
\hline Ketan $\left(\mathrm{V}_{5}\right)$ & $10.22 \mathrm{C}$ & $52.77 \mathrm{~b}$ & $6.09 \mathrm{~d}$ & $605.77 \mathrm{~d}$ & $6.63 \mathrm{e}$ & $0.58 \mathrm{~b}$ \\
\hline
\end{tabular}

Note: Numbers in columns followed by the same letter show no difference according to the Duncan's test at the $5 \%$ level. 
The vegetative growth of the five cassava tested did not show consistency and direct relationship between growth parameters, but from the data in Table 4 . It was found that cassava varieties with medium plant height produced a higher number of segments and a number of branches such as those in Adira-4 and Malang-6. This condition is similar to the results of the study of Ntui et al. (2006), which states that cassava varieties with stems that continue to produce longer segments, fewer internodes and fewer tubers per plant.

Cassava varieties Singgah produces a higher number of tubers, tuber length and weight per tuber and is different from other varieties. The cassava Malang-6 variety has a larger tuber diameter and produces a higher weight per tuber and plantations and is different from other

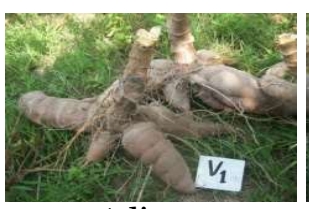

Adira-4

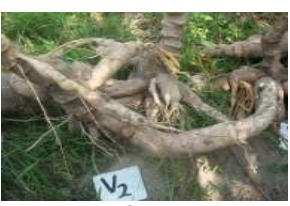

Malang-6

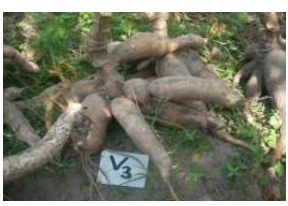

UJ-5

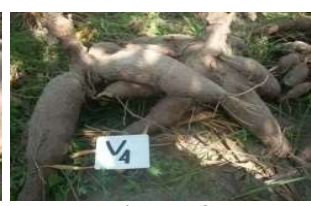

Singgah

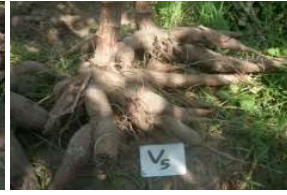

Ketan

Fig. 2. Tuber yields of five cassava varieties aged 4 bst; V: Cassava varieties; V1 Adira-4; V2: Malang-6; V3: UJ-5; V4: Singgah; V5: Ketan.

Dry matter content of cassava is affected by a number of factors such as the age of the plant, season, and various plant locations. Dry matter content of cassava varieties in the range of high value, as reported by Chávez et al. (2005), ranging from $10.7 \%$ to $57.2 \%$, with an average of $34.7 \%$. Various varieties that produce the highest tuber weight, has the lowest dry matter content. There are also some varieties that produce significantly lower weighty tuber with a high dry matter. Ntawuruhunga et al. (2001), and recently Adeniji et al. (2011), reported the results of a similar study on the relationship between the dry matter content and weight of tubers. Dry matter content was significantly negatively correlated with storage root weight. This shows that when the weight of high storage root studied, the dry matter content tends to be low.

Cassava is consumed by taking into account the levels of cyanide and starch in the tuber. There are significant differences between the levels of cyanide and starch of cassava varieties, as presented in Table 5 .

Table 5. Dry matter, HCN and starch content of cassava variety.

\begin{tabular}{|c|c|c|c|c|}
\hline No & Variety & Dry matter (\%) & Content of HCN $\left(\mathrm{mg} \mathrm{kg}^{-1}\right)$ & Content of starch (\%) \\
\hline 1 & Adira-4 $\left(\mathrm{V}_{1}\right)$ & $8.59 d$ & $111.52 \mathrm{c}$ & $24 \cdot 32 d$ \\
\hline 2 & Malang-6 $\left(\mathrm{V}_{2}\right)$ & $8.65 \mathrm{~b}$ & $112.66 \mathrm{c}$ & $28.23 \mathrm{~b}$ \\
\hline 3 & $\mathrm{UJ}-5\left(\mathrm{~V}_{3}\right)$ & $8.68 a$ & $230.17 a$ & $30.26 a$ \\
\hline 4 & Singgah $\left(V_{4}\right)$ & $8.62 \mathrm{c}$ & $136.97 \mathrm{~b}$ & $26.15 \mathrm{c}$ \\
\hline 5 & $\operatorname{Ketan}\left(\mathrm{V}_{5}\right)$ & $8.69 a$ & $103.77 \mathrm{c}$ & $28.85 b$ \\
\hline
\end{tabular}

Note: HCN: Cianida acid, Numbers in columns followed by the same letter show no difference according to the Duncan's test at the 5\% level.

UJ-5 cassava varieties contain the highest $\mathrm{HCN}$, starch content and significantly different from other varieties. The five cassava varieties containing $\mathrm{HCN}$ above $100 \mathrm{mg} \mathrm{kg}^{-1}$ means that including cassava is rather bitter. Sundaresan et al. (1987) classified cassava into three categories based on HCN content, namely non-bitter cassava ( $\mathrm{HCN}<100 \mathrm{mg} \mathrm{kg}^{-1}$ of fresh cassava), bitter cassava (HCN between 100-450 $\mathrm{mg} \mathrm{kg}^{-1}$ of fresh cassava), and very bitter cassava ( $\mathrm{HCN}>$ $450 \mathrm{mg} \mathrm{kg}^{-1}$ of fresh sweet potatoes).

Cassava is a plant that is ideal for integrating into local farmers' crop production systems. This study shows that the three varieties can effectively compete under the conditions of the soil and the environment. Different varieties of cassava will give farmers the opportunity to choose the most suitable cassava for its growing conditions. This study shows that there is great 
variability in the morphological characteristics of the roots and stems of cassava varieties. Morphological characteristics presented in this study will assist farmers in identifying these varieties. Tuber yield can be improved through selection based on components of the results, in particular, plant height, number of bulbs and bulb size (Aina et al., 2007; Akinwale et al., 2010). Selection of cassava varieties with good plant height and good branching habit, will facilitate the implementation of planting and harvesting, and provide quality planting material at the end of the harvest.

Characteristics of cassava tubers play an important role in the recommendation and acceptance of cassava varieties to farmers and consumers. Cassava development programs should be taken into account not only for the performance results of the bulbs, but also must take into account the characteristics of quality. Quality characteristics may be more difficult to assess objectively, however, because they relate to features such as appearance, color, taste and texture.

The results showed differences in the response of cassava varieties with the measured parameter, an indication that these properties depend on the variety. It is therefore important that cassava varieties were evaluated to assess its potential. Additional research is also needed, with respect to the feasibility of cassava production. Introduction and evaluation of new cassava varieties could increase the productivity of local farmers through increased yields for consumption bulbs and stems for planting material, with a minimum of manpower and financial input.

\section{Conclusion}

Cassava varieties Malang- 6 has a rod with highest average number of segments (163.90), followed by 142.44 Adira-4 as much, so it will be very much beneficial if used as source of planting materials. Cassava varieties Malang- 6 presented the highest yield average is 13.81 tones ha-1 followed by Singgah and Adira-4 i.e. 11.98 and 11.11 tons ha ${ }^{-1}$ but the variety 1 yang Ketan which only weighs 6.63 tons $\mathrm{ha}^{-1}$. Harvest index of varieties Adira-4, Malang-6, UJ 5 and Singgah were $0.78,0.77,0.77$ and 0.76 , respectively and the values were higher and significantly form different IP varieties of Ketan is 0.58. Malang-6 varieties and Singgah that produces the highest tuber weight, has a low dry matter content is $8.65 \%$ and $8.62 \%$. The Ketan varieties and UJ-5 has a tuber weight was significantly lower with dry matter content higher than that dried $8.69 \%$ and $8.68 \%$. Dry matter content was significantly negatively correlated with tuber weight, showed that when high tuber weight, then dry matter content tends to be low.

\section{References}

Adeniji, O.T., Odo, P.E. and Ibrahim, B. 2011. Genetic relationships and selection indices for cassava root yield in Adamawa State, Nigeria. African J. Agril. Res. 6(13): 29312934.

Aina, O.O., Dixon, A.G.O. and Akinrinde, E.A. 2007. Genetic variability in cassava as it influences storage root yield in Nigeria. $J$. Biol. Sci. 7: 765-770.

https://doi.org/10.3923/jbs.2007.765.770

Akinwale, M.G., Akinyele, B.O., Dixon, A.G.O. and Odiyi, A.C. 2010. Genetic variability among forty-three cassava genotypes in three agro-ecological zones of Nigeria. $J$. Plant Breed. Crop Sci. 2(5): 104-109.

Alexandratos, N. ed. 1995. World Agriculture: Towards 2010: A FAO Study, Chichester, England. Food and Agriculture Organization of the United Nations; John Willey and Sons. pp. xxvi +488 .

Alves, A.A.C. 2002. Cassava botany and physiology. In: Hillocks, R.J., Thresh, J.M. and Bellotti, A.C. (Eds.). Cassava: biology, production and utilization. UK: CABI Publishing. pp. 67-89.

https://doi.org/10.1079/9780851995243.0067

Amarullah, Indradewa, D., Yudono, P. and Sunarminto, B.H. 2016. Photosynthetic activity of superior varieties super and local Cassava (Manihot esculenta Crantz) in Indonesia. J. Agril. Sci. 8(8): 194-200. https://doi.org/10.5539/jas.v8n8p194

Chávez, A.L., Sánchez, T., Jaramillo, G., Bedoya, J.M., Echeverry, J., Bolaños, E.A., Ceballos, H. and Iglesias, C.A. 2005. Variation of quality traits in cassava roots evaluated in landraces and improved clones. Euphytica. 143: 125-133. https://doi.org/10.1007/s10681005-3057-2

CIAT. 2009. Key access and utilization descriptors for cassava genetic resources. Bioversity International, Rome, Italy, International Center for Tropical Agriculture (CIAT), Cali, Colombia. 5p.

Eze, S.C. and Ugwuoke, K.I. 2010. Evaluation of different stem portions of cassava (Manihot esculentus) in the management of its establishment and yield. Res. J. Agric. Biol. Sci. 6(2): 181-185.

Hayford, M.A. 2009. Growth, Yield and Quality of Cassava as Influenced by Terramend 21, Poultry Manure and Inorganic Fertilizer. Master of Agronomy Thesis, School of Graduate Studies, Kwame Nkrumah University of Science and Technology (KNUST), Kumasi, Ghana. 66p. 
Hillocks, R.J., Thresh, J.M. and Bellotti, A.C. ed. 2002. Cassava: biology, production and utilization. New York: CABI Publishing. 332p. https://doi.org/10.1079/9780851995243.0000

Ikeh. A.O., Udaeyo. N.U., Udoh. E.I., Iboko.K.O. and Udounang. P.I. 2012. Growth and yield of Cassava (Manihot esculenta Crants) as influenced by the number of shoots retained per stand on as Ultisol. Nat. Sci.10(8): 1720. http://www.sciencepub.net/nature

Irikura, Y., Cock, J.H. and Kawano, K. 1979. The physiological basis of genotype-temperature interactions in cassava. Field Crops Res. 2: 227-239. https://doi.org/10.1016/03784290(79)90025-X

Ladeira, T., Souza, H. and Pena, R. 2013. Characterization of the roots and starches of three cassava cultivars. Int. J. Agril. Sci. Res. 2(1): 12-20.

Lebot, V. 2009. Tropical roots and tuber crops: cassava, sweet potato, yams and aroids. Crop Production science in horticulture series. 17, CABI Publishing, UK. pp. 50-103. https://doi.org/10.1079/9781845934248.0000

Neppl, G.P., Wehner, T.C. and Schultheis, J.R. 2003. Interaction of border and center rows of multiple row plants in watermelon yield trials. Euphytica. 131: 225-234. https://doi.org/10.1023/A:1023958321626

Nnodu, E.C., Ezulike, T.O. and Asumugha, G.N. 2006. Cassava. In: Idem NUA, Showemimo FA (eds.). Tuber and Fibre Crops of Nigeria: Principles of production and Utilization. 2006: (XXII), 239p.

Ntawuruhunga, P. and Dixon, A. 2010. Quantitative variation and interrelationship between factors influencing cassava yield. $J$. Appl. Biosci. 26: 1594-1602.

Ntawuruhunga, P., Rubaihaho, P.R., Whyte, J.B. A., Dixon, A.G.O. and Osiru, D.S.O. 2001. Inter-relationships among traits and path analysis for yield components of cassava: A search for storage root yield indicators. African Crop Sci. J. 9: 599-606. https://doi.org/10.4314/acsj.v9i4.27582

Ntui, V.O., Uyoh, E.A., Affangideh, U., Udensi, U. and Egbonyi, J.P. 2006. Correlation and genetic variability in cassava (Manihot esculenta Crantz). J. Food Agric. Environ. 4(3/4): 147-150.

Perera, P.I., Quintero, M., Dedicova, B., Kularatne, J.D. and Ceballos, H. 2013. Comparative morphology, biology and histology of reproductive development in three lines of Manihot esculenta Crantz (Euphorbiaceae: Crotonoideae). AoB Plants. 5: pls046. https://doi.org/10.1093/aobpla/plso46

Plucknett, D.L., Phillips, T.P. and Kagbo, R.B. 1998. A Global Development Strategy for Cassava: Transforming a Traditional Tropical Root Crop: Sparing Rural Industrial Development and Raising Incomes for the Rural Poor. Available online: http://www.fao.org/docrep/o06/y0169e/y0169e 04.htm (accessed 9 August 2011).

Raji, A.A.J., Anderson, J.V., Kolade, O.A., Ugwu, C.D., Dixon, A.G.O. and Ingelbrecht, I.L. 2009. Gene-based microsatellites for cassava (Manihot esculenta Crantz): prevalence, olymorphisms, and cross-taxa utility. BMC Plant Biol. 9: 118. https://doi.org/10.1186/1471-2229-9-118

Ristono and Amarullah. 2011. Singkong Gajah Berjuang (Indonesian). Petrogas Press. Cetakan II. Balikpapan. 202p.

Romani, M., Borghi, B., Alberici, R., Delogu, G., Hesselbach, J. and Salamini, F. 1993. Intergenotypic competition and border effect in bread wheat and barley. Euphytica. 69: 19-31. https://doi.org/10.1007/BFooo21722

SAS. 2004. Statistical Analysis System for Windows 9.0. SAS Institute Inc. SAS Campus Drive. Cary. North Carolina. USA. $5121 \mathrm{p}$.

Sundaresan, S., Nambisan, B. and Eswari, A. 1987. Bitterness in cassava in relation to cyanoglucoside content. Indian J. Agric. Sci. 57: 37-40.

Ziska, L., Runion, G.B., Tomecek, M., Prior, S.A., Torbet, H.A. and Sicher, R. 2009. An evaluation of cassava, sweet potato and field corn as potential carbohydrate sources for bioethanol production in Alabama and Maryland. Biomass and Bioenergy. 33: 1503-1508.

https://doi.org/10.1016/j.biombioe.2009.07.014 